\author{
Marek Błaszczyk \\ (D) https://orcid.org/0000-0001-5518-0115 \\ Uniwersytet Mikołaja Kopernika w Toruniu
}

\title{
Problem relacji międzypodmiotowych w egzystencjalizmie
}

https://doi.org/10.15633/9788374389952.03

Celem artykułu będzie ukazanie specyfiki relacji międzypodmiotowych w szeroko rozumianej filozofii egzystencjalnej (egzystencjalizmie). Zaznaczymy, nawiązując do wybranych filozofów egzystencjalnych, że relacje międzypodmiotowe mogą przybierać charakter przedmiotowy (celem jest tutaj dążenie do „zawłaszczenia”, uprzedmiotowienia Innego), bezosobowy (celem jest tu konfrontacja jednostki z „anonimowym” społeczeństwem, zdepersonalizowanym „tłumem”) oraz osobowy (celem jest tutaj nawiązanie dialogu, trwałej komunikacji z Innym). Będziemy argumentować na rzecz tezy, że jednostka nie jest w stanie w pełni wyjaśnić samej siebie, swego miejsca i roli w świecie, nie konfrontując swej egzystencji z Innym (drugim człowiekiem). Samorozumienie możliwe jest bowiem na drodze rozumienia Innego.

Wywód podzielony będzie na cztery części. W pierwszej nakreślimy fenomen egzystencjalizmu, wskazując na jego genezę, specyfikę oraz najważniejszych przedstawicieli. Podkreślimy, że jest to nurt niejednorodny i programowo antysystemowy, akcentujący filozoficzną rangę ludzkiego sposobu bycia-w-świecie. Powiemy, że głównym przedmiotem zainteresowania egzystencjalistów jest człowiek i „sprawy ludzkie”, w tym poszukiwanie odpowiedzi na pytanie o sens i cel ludzkiego życia. W drugiej przyjrzymy się Sartre'owskiej koncepcji relacji międzypodmiotowych, zwracając uwagę na ich przedmiotowy charakter. Zaznaczymy, że cechują się one dążeniem do uprzedmiotowienia Innego, a motorem ich realizacji jest walka i konflikt. Drugi człowiek jest tutaj traktowany jako ktoś, kto nieustannie zagraża naszej wolności; jego reifikujące spojrzenie generuje w nas niepokój, ograniczając nasze zdolności autokreacyjne. W trzeciej przedstawimy bezosobową relację jednostki do anonimowego społeczeństwa (Się), odwołując się do rozpoznań Martina Heideggera. 
Się („nieokreślona mnogość”), wedle tego ujęcia, przyczynia się do tłumienia ludzkiej autentyczności, afirmując wyłącznie to, co nieproblematyczne, przewidywalne, powszechnie obowiązujące. W czwartej części, nawiązując do filozofii Gabriela Marcela, przybliżymy natomiast specyfikę osobowej relacji z Innym. Podkreślimy, że jej celem jest nawiązanie dialogu i porozumienia z drugim człowiekiem. Jego egzystencja nie tylko przy tym wymyka się uprzedmiotowieniu, ale i stanowi istotny punkt odniesienia $\mathrm{w}$ definiowaniu naszego własnego życia (bycia-w-świecie). Dzięki Innemu możemy bowiem realizować autentyczny sposób istnienia, osiągając wyższy poziom samorozumienia.

\section{Fenomen egzystencjalizmu}

Egzystencjalizm jest jednym z ważniejszych nurtów myśli współczesnej. Jego przedstawicielami - jak się najczęściej przyjmuje - są bowiem tacy filozofowie jak: Martin Heidegger, Karl Jaspers, Gabriel Marcel, Jean-Paul Sartre, Simone de Beauvoir czy Albert Camus ${ }^{1}$. Jego korzeni szukać można jednak już u Sørena Kierkegaarda i Fryderyka Nietzschego ${ }^{2}$. Oni też przeważnie uchodzą za jego prekursorów. Z egzystencjalizmem łączy się również filozofię Blaise’a Pascala ${ }^{3}$ oraz św. Augustyna ${ }^{4}$. Niektórzy badacze egzystencjalizmu jego genezy dopatrują się nawet w Starym Testamencie, przywołując duchowe rozterki Koheleta czy Hioba ${ }^{5}$. Sarah Bakewell nie pozostawia tu wątpliwości: motywy egzystencjalne można odnaleźć u „każdego, kto kiedykolwiek czuł się niezadowolony, zbuntowany bądź wyobcowany z jakiegokolwiek powodu" ${ }^{6}$. Egzystencjalizm jawi się więc jako filozofia wieczna i uniwersalna (philosophia perennis), dotykająca fundamentalnych

1 Na gruncie polskiej nauki za najszerzej zakrojoną antologię egzystencjalizmu uznać można wydaną w 1965 roku publikację Filozofia egzystencjalna, zredagowaną przez Leszka Kołakowskiego i Krzysztofa Pomiana. Znajdziemy w niej fragmenty dzieł takich filozofów jak: Søren Kierkegaard, Max Stirner, Friedrich Nietzsche, Max Scheler, Miguel de Unamuno, Karl Jaspers, Gabriel Marcel, Lew Szestow, Martin Heidegger, Nicola Abbagnano, Jean-Paul Sartre, Georges Bataille, Albert Camus oraz Maurice Merleau-Ponty. Por. Filozofia egzystencjalna, red. L. Kołakowski, K. Pomian, Państwowe Wydawnictwo Naukowe, Warszawa 1965.

2 M. Warnock, Egzystencjalizm, przeł. M. Michowicz, Prószyński i S-ka, Warszawa 20o6, s. 11.

3 M. Błaszczyk, Pascal jako prekursor filozofii egzystencjalnej, „Przegląd Filozoficzny” (2017) nr 3, s. 149-162.

4 W. Kaufmann, Existentialism: from Dostoevsky to Sartre, New American Library, New York 1975.

5 M. Friedman, The Worlds of Existentialism, Random House, New York 1964.

6 S. Bakewell, Kawiarnia egzystencjalistów, przeł. A. Paszkowska, Wydawnictwo Krytyki Politycznej, Warszawa 2018, s. 9. 
problemów człowieka ${ }^{7}$. Jest, jak mawiał Jaspers, „pewną postacią jednej,

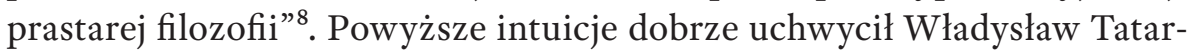
kiewicz, wedle którego „egzystencjaliści bywali zawsze”.

Warto zaznaczyć, że egzystencjalizm jest nie tylko nurtem intelektualnym (filozoficznym), ale także pewną osobliwą formacją literacką i artystyczno-kulturową. Problematyka egzystencjalna szczególnie zaś obecna jest w twórczości takich pisarzy jak: Fiodor Dostojewski, Franz Kafka, Hermann Hesse, Witold Gombrowicz czy Edward Stachura. Dodajmy, że Notatki z podziemia Dostojewskiego uchodzą za znakomite wprowadzenie do tego ruchu myślowego ${ }^{10}$.

Egzystencjalizm nie jest zwartą doktryną czy systemem filozoficznym. Jest to bowiem nurt istotowo zróżnicowany i niejednolity, krytyczny wobec wszelkiej wiedzy naukowej, a zarazem daleki od formułowania „totalnych” sądów o ludzkim istnieniu. Niechęć egzystencjalistów do konstruowania systemów filozoficznych spowodowana jest właśnie świadomością niewystarczalności oraz nadmiernej abstrakcyjności kategorii intelektualnych, za pomocą których próbuje się opisać jednostkowe doświadczenie egzystencjalne. Jak wyzna Karl Jaspers: „Przekonałem się, że większość teorii filozoficznych, a i wiele naukowych, nie daje żadnej pewności. [...] to, co słynni uczeni podają w podręcznikach jako wiedzę naukową, często nie zostało krytycznie zweryfikowane i w rzeczy samej wcale nie jest pewne. Dostrzegałem czczą gadaninę, pozorne poznanie"11. Możemy więc powiedzieć, że egzystencjalizm jest krytyką filozofii systemowej (filozofii esencji), bazującej w znacznej mierze na Kartezjańskim cogito, ergo sum. Stąd nie „myśl”, gloryfikowana przez krąg filozofów-racjonalistów, lecz „bycie” sytuuje się w centrum dociekań egzystencjalistów. Ich credo - trawestując słynne założenie Kartezjusza - zdaje się stanowić formuła „jestem, więc myślę"12.

Egzystencjalizm, jak przekonuje Bakewell, to „bardziej nastrój niż filozofia"13. Poznanie egzystencjalne nie jest tym samym poznaniem czystym

7 M. Błaszczyk, Rozmowy w kawiarni. O fenomenie egzystencjalizmu, „Świat i Słowo” (2019) nr 2, s. $277-284$.

8 K. Jaspers, Filozofia egzystencji, przeł. D. Lachowska, w: K. Jaspers, Filozofia egzystencji, przeł.

D. Lachowska, A. Wołkowicz, PIW, Warszawa 1990, s. 159.

9 W. Tatarkiewicz, Historia filozofi, t. 3, Wydawnictwo Naukowe PWN, Warszawa 2005, s. 397.

10 W. Kaufmann, Existentialism: from Dostoevsky to Sartre, s. 12-14.

11 K. Jaspers, O mojej filozofii, przeł. D. Lachowska, w: K. Jaspers, Filozofia egzystencji, dz. cyt., s. 60.

12 Por. P. Roubiczek, Existentialism. For and Against, Cambridge University Press, Cambridge 1964, s. $8-9$.

13 S. Bakewell, Kawiarnia egzystencjalistów, s. 9. 
(obiektywnym), pozbawionym emocji, jak zalecał Baruch Spinoza czy Georg Wilhelm Friedrich Hegel, lecz zrelatywizowanym do poznawczych filtrów człowieka jako egzystencji. Wszystko to, paradoksalnie, czyni egzystencjalizm swego rodzaju antyfilozofią. Paradoksalnie jednak, bowiem taki właśnie sposób filozofowania zdaje się być najbliższy źródłowemu pojęciu filozofii jako „myślenia zaangażowanego”. Słusznie Mikołaj Bierdiajew konstatuje, że

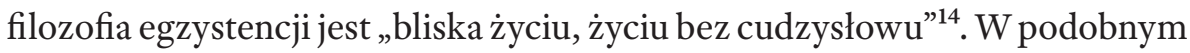
duchu, dodajmy, utrzymane są także wypowiedzi Lwa Szestowa ${ }^{15}$, Emmanuela Lévinasa ${ }^{16}$ czy Karla Jaspersa, akcentującego „nierozdzielność filozofowania i bycia człowiekiem"17.

Głównym przedmiotem zainteresowania egzystencjalistów nie jest podmiot transcendentalny (abstrakcyjny, zaświatowy, zdepersonalizowany), lecz człowiek konkretny, „z krwi i kości”, który „rodzi się, cierpi, umiera - przede wszystkim umiera - który je, pije, bawi się i śpi, myśli i kocha, człowiek, którego się widzi i słyszy"18. Mówiąc inaczej, egzystencjaliści zarówno w swej twórczości filozoficznej, jak i literackiej - zwracają uwagę na fenomen jednostkowego doświadczenia egzystencjalnego (,jedynie człowiek egzystuje"19), koncentrując się na problemach bezpośrednio związanych z ludzkim życiem.

Wspomnieliśmy wyżej, że egzystencjalizm jest nurtem niejednorodnym, programowo wręcz antysystemowym. Niezwykle trudno dokonać więc jego naukowej konceptualizacji. Można nawet odnieść wrażenie, że wszelkie jej próby nieuchronnie skazane są na porażkę, nie sposób bowiem wypracować ogólnej teorii ludzkiej egzystencji. Nie ma przy tym jednego egzystencjalizmu - mamy raczej do czynienia z wieloma filozofiami egzystencji (egzystencjalizmami). Niemniej jednak niekiedy wyróżnia się egzystencjalizm ateistyczny i chrześcijański ${ }^{20}$, niemiecką filozofię egzystencji i francuski egzy-

14 M. Bierdiajew, Autobiografia filozoficzna, przeł. H. Paprocki, Wydawnictwo Antyk, Kęty 2002, S. 29.

15 L. Szestow, Ateny i Jerozolima, przeł. C. Wodziński, Znak, Kraków 1993, s. 82.

16 E. Levinas, Odkrywając egzystencję z Husserlem i Heideggerem, przeł. E. Sowa, Wydawnictwo IFiS PAN, Warszawa 2008, s. 87.

17 K. Jaspers, Wprowadzenie do filozofii, przeł. A. Wołkowicz, Siedmioróg, Wrocław 1998, s. 87.

18 M. de Unamuno, O poczuciu tragiczności życia wśród ludzi i wśród narodów, przeł. H. Woźniakowski, Wydawnictwo Literackie, Kraków, Wrocław 1984, s. 5.

19 M. Heidegger, Czym jest metafizyka? Wprowadzenie, przeł. K. Wolicki, w: M. Heidegger, Znaki drogi, przeł. S. Blandzi i in., Wydawnictwo Spacja, Warszawa 1999, s. 320.

20 J.P. Sartre, Egzystencjalizm jest humanizmem, przeł. J. Krajewski, Warszawskie Wydawnictwo Literackie Muza, Warszawa 1998, s. 23. 
stencjalizm ${ }^{21}$ oraz egzystencjalizm autoekspresji i egzystencjalizm filozofii ${ }^{22}$. Warto wszakże nadmienić, że są to klasyfikacje dość umowne, ponieważ nie wyczerpują one wszystkich możliwych interpretacji tegoż nurtu. Pozostawiając na boku kwestię trafności owych rozpoznań, nie można nie zauważyć, że wspólny egzystencjalistom jest pewien specyficzny „klimat myślenia”23, przejawiający się w podejmowaniu zagadnień dotyczących konkretnej ludzkiej egzystencji, jej uwikłania w świat, własne bycie oraz międzypodmiotowe relacje.

\section{Uprzedmiotowienie Innego}

Relacja człowieka ze światem rzeczy, zdaniem Jeana-Paula Sartre’a, uchodzi za podstawową relację wewnątrzświatową. Wynika ona bezpośrednio z faktu, że jednostka jest „rzucona” w świat, że zawsze jest-już-w-świecie. Owo „rzucenie” ma charakter jedynie przypadkowy, nie ma tu więc mowy o jakiejkolwiek przyczynowości. O wyborze miejsca i czasu swoich narodzin nie zadecydowałem bowiem ja sam; nie ja też wybrałem warunki geopolityczne i środowisko rodzinne, które od momentu mego urodzenia stanie się „moje”. Świat, w którym przyjdzie mi wzrastać i się rozwijać, jest światem przeze mnie zastanym, zewnętrznym i ode mnie niezależnym. Niemniej jednak ów świat jest zawsze „oglądany” przeze mnie, z mojej tylko perspektywy i z mojego punktu widzenia. W tym sensie zdaje się być do mnie całkowicie zrelatywizowany. Życie w nim oznacza natomiast konieczność permanentnego odnoszenia się do niego, bycia-w-nim, a co za tym idzie, nawiązywania relacji z napotykanymi w nim bytami.

Rzeczy, jak twierdzi Martin Heidegger, każdorazowo jawią mi się jako poręczne, mogę więc wykorzystywać ich funkcjonalność na własny użytek, „dostrajać” je do swoich potrzeb, zmagając się z oporem, jaki mi stawiają. Rzeczy zarazem pośredniczą w moim kontakcie z Innym, bowiem to właśnie

O. F. Bollnow, Deutsche Existenzphilosophie und Französischer Existentialismus, „Zeitschrift für Philosophische Forschung" 2 (1948) H. 2/3, s. 231-243; O. F. Bollnow, Existenzphilosophie, Kohlhammer, Stuttgart 1955; H. Arendt, Czym jest filozofia egzystencji?, w: H. Arendt, Salon berlinski i inne eseje, przeł. M. Godyń, S. Szymański, Prószyński i S-ka, Warszawa 2008, s. 73-102; H. Arendt, Francuski egzystencjalizm, w: H. Arendt, Salon berliński i inne eseje, dz. cyt., s. 105-112.

22 M. Siemek, Nad egzystencjalizmem, w: M. Siemek, W kręgu filozofów, Czytelnik, Warszawa 1984, s. 205-213.

23 W. Luijpen, Fenomenologia egzystencjalna, przeł. B. Chwedeńczuk, PAX, Warszawa 1972, s. 7. 
przez ich pryzmat pierwotnie postrzegam drugiego człowieka ${ }^{24}$. Heidegger przy tym konstatuje, dodajmy na marginesie, że ludzka egzystencja ma charakter „bycia-z” (współbycia). Oznacza to, że człowiek, będąc-w-świecie, nie istnieje w izolacji, lecz zawsze wspólnie z innymi ludźmi (Mitsein). Być na sposób Dasein znaczy więc być wraz z innymi, współegzystować: „Na podstawie tego wspólnego bycia-w-świecie świat zawsze jest już przeze mnie dzielony z innymi. Świat jestestwa to wspótświat (Mitwelt). Bycie-w to współbycie $\mathrm{z}$ innymi. Ich wewnątrzświatowe bycie-w-sobie ma charakter wspótjestestwa” ${ }^{25}$. W innym miejscu niemiecki filozof nadmienia, że ,jestestwo jako bycie-w-świecie jest zarazem współbyciem z innym jestestwem” ${ }^{26}$; „ponieważ do podstawowego ukonstytuowania jestestwa należy bycie-w-świecie, egzystujące jestestwo jako bycie przy wewnątrzświatowym bycie jest $\mathrm{z}$ istoty współbyciem z innymi” ${ }^{27}$; „bycie-w-świecie jest współbyciem z innymi niezależnie od tego, czy i jak inni faktycznie współbytują"28. Warto jednak pamiętać, że Heideggerowska wizja człowieka jest raczej monologiczna niż dialogiczna. Zwraca na to uwagę Martin Buber, zaznaczając, że pierwszorzędnym celem egzystencji, zdaniem Heideggera, nie tyle jest ukonstytuowanie ludzkiej wspólnoty (opartej o pryncypia dialogiczne), ile dążenie do samorozumienia i autentyczności („bycia sobą”). W tym sensie inni ludzie są niejako „podporządkowani” Dasein, stanowiąc obiekty (przedmioty), które ono stara się zrozumieć. Właściwe „bycie sobą” poprzedza tym samym dialogiczne współistnienie z Innym. Filozofia Heideggera, konkluduje Buber, nie ukazuje „jedności człowieka z człowiekiem”29, lecz jednostkę samotną, zatroskaną o swoje bycie-w-świecie.

Sartre, nawiązując do rozpoznań Heideggera, podkreśla, że komunikacja z drugim człowiekiem jest zagadnieniem wtórnym wobec problemu jednostkowej wolności. Wolność jest bowiem centralnym przedmiotem jego

24 Por. M. Heidegger, Bycie i czas, przeł. B. Baran, Wydawnictwo Naukowe PWN, Warszawa 2010, s. 143-146. Szerzej na ten temat zob. H. Dreyfus, Being-with-Other, w: The Cambridge Companion to Heidegger's Being and Time, ed. M. Wrathall, Cambridge University Press, Cambridge 2013, s. 145156; G. Figal, Martin Heidegger. Phänomenologie der Freiheit, Mohr Siebeck, Tübingen 2013, s. 118122; W. Rymkiewicz, Ktoś i nikt. Wprowadzenie do lektury Heideggera, Wydawnictwo Uniwersytetu Wrocławskiego, Wrocław 2002, s. 98-10o.

25 M. Heidegger, Bycie i czas, dz. cyt., s. 164.

26 M. Heidegger, Podstawowe problemy fenomenologii, przeł. B. Baran, Fundacja Aletheia, Warszawa 2009 , s. 310 .

27 M. Heidegger, Podstawowe problemy fenomenologii, dz. cyt., s. 299.

28 M. Heidegger, Podstawowe problemy fenomenologii, dz. cyt., s. 299.

29 M. Buber, Problem człowieka, przeł. J. Doktór, Wydawnictwo Naukowe PWN, Warszawa 1993, s. 58 . 
filozoficznego zainteresowania, stanowi kluczowy warunek „bycia sobą”, autokreacji i samostanowienia ${ }^{30}$. Autor Bytu i nicości przekonuje, że wolność jest wartością nadrzędną, nierozerwalnie związaną z ludzką egzystencją: „Człowiek jest wolnością"31, „człowiek skazany jest na wolność”32. Tak rozumiana wolność - przy jednoczesnym zakwestionowaniu obowiązujących norm moralnych - niechybnie prowadzi do samotności (,jesteśmy sami, nikt nas nie usprawiedliwi”" ${ }^{33}$. Człowiek Sartre’a, odrzucając istnienie Boga i tradycyjnego systemu aksjologicznego, jest „projektem przeżywanym subiektywnie" ${ }^{34}$, a jego egzystencja (istnienie) nieustannie poprzedza esencję (istotę). Jak powie filozof: „Człowiek najpierw istnieje, zdarza się, powstaje w świecie, a dopiero później się definiuje. Człowieka w pojęciu egzystencjalisty nie można zdefiniować dlatego, że jest on pierwotnie niczym. Będzie on czymś dopiero później, i to będzie takim, jakim się sam uczyni. A więc nie ma natury ludzkiej, ponieważ nie ma Boga, który by ją w umyśle swym począł. Człowiek jest nie tylko taki, jakim siebie pojmuje, lecz również taki, jakim chce być, jakim się pojął po zaistnieniu i jakim zapragnął być po tym skoku w istnienie. Człowiek jest tylko tym, czym siebie uczyni" ${ }^{35}$. Mówiąc najogólniej: człowiek jest głównym architektem swego życia - on też ponosi odpowiedzialność za jego przebieg. Wszelkie próby „usprawiedliwiania” swoich poczynań (np. poprzez odwoływanie się do „przeznaczenia”, fatum czy Bożego planu) są natomiast postrzegane przez Sartre'a w kategoriach „złej wiary”36, a tym samym zanegowania swojej autentyczności, ontycznej wyjątkowości i indywidualności.

Człowiek Sartre’a, projektując swą egzystencję (jako byt-dla-siebie), konfrontuje się ze światem rzeczy (byt-w-sobie) oraz innymi ludźmi (byt-dla-Innego). Świat rzeczy, a więc otaczająca go rzeczywistość, charakteryzuje się przypadkowością, niezmiennością (ontologiczną trwałością) oraz „masywnością”. Rzeczy (byty-w-sobie), mówiąc inaczej, nie posiadają (samo) świadomości, są statyczne, nieprzejrzyste (bo bez reszty wypełnione sobą) i w pełni obecne, „narzucające się”; są tym, czym są: „Byt-w-sobie nie ma

30 M. Błaszczyk, Człowiek wedtugJeana-Paula Sartre’a, „Przegląd Filozoficzny” (2019) nr 2, s. 39-52.

31 J. P. Sartre, Egzystencjalizm jest humanizmem, dz. cyt., s. 38.

32 J. P. Sartre, Egzystencjalizm jest humanizmem, dz. cyt., s. 39.

33 J. P. Sartre, Egzystencjalizm jest humanizmem, dz. cyt., s. 39.

34 J.P. Sartre, Egzystencjalizm jest humanizmem, dz. cyt., s. 27.

35 J. P. Sartre, Egzystencjalizm jest humanizmem, dz. cyt., s. 26-27.

36 J. P. Sartre, Byt i nicość. Zarys ontologii fenomenologicznej, przeł. J. Kiełbasa i in., Wydawnictwo Zielona Sowa, Kraków 2007, s. 83-112. 
żadnego $w n e ̨ t r z a$, które przeciwstawiałoby się jakiejś zewnętrzności, i które byłoby analogiczne do jakiegoś sądzenia, jakiegoś prawa, jakiejś świadomości siebie. Byt-w-sobie nie skrywa żadnej tajemnicy: jest masywny" "37. Byt-w-sobie jawi się więc jako swoista „synteza sobości” („siebie z sobą”), pozbawiona pierwiastka sprawczości (decyzyjności) oraz wymykająca się czasowości. Wprawdzie można go pomyśleć $\mathrm{z}$ perspektywy przeszłości lub przyszłości, jednak nie oznacza to, że traci on wówczas „pełnię swego bytu”, w tym swoją „masywność”. Jak konstatuje Sartre: „Byt jest. Byt jest w sobie. Byt jest tym, czym jest" ${ }^{\prime 3}$.

Byt-w-sobie jest także całkowicie przypadkowy, zbędny. Nie można go bowiem wyprowadzić zarówno ze sfery możliwości, potencjalności (charakterystycznej dla bytu-dla-siebie), jak i ze sfery konieczności (mogącej „przysługiwać” jedynie Bogu). Myśl tę doskonale przedstawił filozof w powieści Mdłości, w której czytamy: „Zasadniczą sprawą jest przypadkowość. Chcę przez to wyrazić, że istnienie z samej definicji nie jest koniecznością. Istnieć to znaczy być tutaj, po prostu; rzeczy istniejące ukazują się, pozwalają się napotykać, ale nigdy nie można ich wywnioskować”39. I nieco dalej: „Żaden byt konieczny nie może wytłumaczyć istnienia. Przypadkowość nie jest złudzeniem, pozorem, który można rozproszyć; to absolut, w konsekwencji doskonała bezpodstawność" 40 .

Byt-w-sobie zdaje się być przy tym podstawowym punktem odniesienia dla bytu-dla-siebie. To właśnie poprzez napotykane w świecie przedmioty człowiek może poznać siebie samego, swoje egzystencjalne usytuowanie, które najczęściej objawia się doświadczeniem samotności, obcości i obrzydzenia („mdłości”). Człowiek, rozumiany jako byt-dla-siebie, jest zatem bytem, który „nie jest tym, czym jest, i jest tym, czym nie jest”41. Jego istnienie wydarza się natomiast w przestrzeni współbycia (Heidegger mówi tutaj o fenomenie Mitdasein), odnosząc się do Innego („byt-dla-siebie odsyła do bytu-dla-innego" ${ }^{22}$ ). W tym sensie egzystencja jest zawsze koegzystencją - relacja jednostki ze światem jest zarazem relacją z innymi bytami-dla-siebie: „Świat istnieje dla podmiotu, jawiąc się jego świadomości, a świadomość istnieje dla

37 J. P. Sartre, Byt i nicość. Zarys ontologii fenomenologicznej, dz. cyt., s. 28.

38 J. P. Sartre, Byt i nicość. Zarys ontologii fenomenologicznej, dz. cyt., s. 29.

39 J. P. Sartre, Mdtości, przeł. J. Trznadel, PIW, Warszawa 1974, s. 185.

40 J. P. Sartre, Mdtości, dz. cyt., s. 185.

41 J. P. Sartre, Byt i nicość, dz. cyt., s. 122.

42 J. P. Sartre, Byt i nicość, dz. cyt., s. 289. 
siebie tylko przez mediację innych ludzi i rzeczy" ${ }^{43}$. Co znamienne, Sartre zaznacza, że spojrzenie drugiego człowieka nas zniewala i reifikuje, ograniczając tym samym naszą wolność.

Radykalną konsekwencją ludzkiej wolności, która zdaniem Sartre’a ma wymiar absolutny, jest uprzedmiotowienie Innego. Chodzi tu nie tylko o postrzeganie go przez pryzmat roli czy funkcji, jaką pełni on w społeczeństwie, lecz także - a może właśnie przede wszystkim - o ujmowanie go jako poręcznego „narzędzia”, służącego do zaspokajania naszych potrzeb. Drugi człowiek nie jest tym samym traktowany w kategoriach indywidualnej i niepowtarzalnej osoby (egzystencji), lecz jedynie w kontekście „środka”, dzięki któremu możemy realizować własne projekty życiowe. Zasadniczym motorem stosunków międzyludzkich jest więc egoizm, walka i nieustanny konflikt. Uprzedmiotowienie jest przy tym procesem obustronnym: ja reifikuję Innego, Inny zaś reifikuje mnie. Ludzie, których napotykam, będąc-w-świecie, sprawiają, że czuję się zagrożony. Ich oceniające spojrzenia, ingerując w moją egzystencję, generują we mnie niepokój. Inny, jak pisze Sartre, „jawi się jako radykalne zaprzeczenie mojego doświadczenia, jest bowiem tym, dla kogo jestem przedmiotem, a nie podmiotem" ${ }^{44}$. A skoro on redukuje mnie do rzeczy, ja odwzajemniam się tym samym: „Podczas gdy ja usiłuję wyzwolić się spod wpływu Innego, Inny próbuje uwolnić się ode mnie; kiedy ja staram się zniewolić Innego, Inny stara się zniewolić mnie"45. Inny, jak nietrudno zauważyć, zagraża mej wolności. Gdy ulegam jego spojrzeniu, pozwalając się uprzedmiotowić, staję się jego niewolnikiem.

Dążenie do uprzedmiotowienia Innego przekreśla możliwość nawiązania z nim trwałej, satysfakcjonującej relacji, opartej na dialogu, szacunku, tolerancji czy solidarności. Jest natomiast konieczne, aby urzeczywistnić autentyczny sposób istnienia. Jeśli bowiem „oddam” swoją wolność w ręce

43 W. Gromczyński, Człowiek, światrzeczy, Bóg wilozofii Sartre’a, Państwowe Wydawnictwo Naukowe, Warszawa 1969, s. 11. Por. W. Gromczyński, Egzystencjalizm Jeana Paula Sartre’a, w: Filozofia XX wieku, t. 1, red. Z. Kuderowicz, Wiedza Powszechna, Warszawa 2002, s. 202-220; H.J. Blackham, Six existentialist thinkers, Routledge \& Kegan Paul, London 1956, s. 111-114; T. R. Flynn, Sartre and the Poetics of History, $\mathrm{w}$ : The Cambridge Companion to Sartre, ed. Ch. Howells, Cambridge University Press, Cambridge 1992, s. 213-260.

44 J. P. Sartre, Byt inicość, dz. cyt., s. 296.

45 Cyt. za M. Warnock, Egzystencjalizm, dz. cyt., s. 136. Por. M. Natanson, The Problem of Others in 'Being and Nothingness', w: The Philosophy of Jean-Paul Sartre, red. P.A. Schilpp, Open Court, La Salle, Illinois 1991, s. 326-344; M. Żelazny, Filozofia i psychologia egzystencjalna, Wydawnictwo Naukowe UMK, Toruń 2011, s. 338-347; J. Bukowski, Problem Innego u Sartre’a, „Teksty: teoria literatury, krytyka, interpretacja" (1981) nr 3 (57), s. 142-151. 
drugiego człowieka, sam dla siebie stanę się przedmiotem. Mogę więc albo zanegować siebie, afirmując Innego, albo dokonać jego neantyzacji, „odzyskując" siebie i swoją wolność. Harmonijna, bezkonfliktowa koegzystencja (współbycie) nie jest tym samym możliwa („piekło to inni”46). Mówiąc inaczej, jeśli nie uprzedmiotowię Innego, on uprzedmiotowi mnie, odbierając mi prawo do autentyczności: „Wykluczam innego przez sam fakt bycia sobą; inny jest tym, kto mnie wyklucza, będąc sobą, i tym, kogo ja wykluczam, będąc sobą" ${ }^{47}$. „W sposób absolutny każdy jest bytem-dla-siebie tylko o tyle, o ile staje w opozycji do innego. Właśnie wobec innego i przeciw innemu potwierdza swoje prawo do bycia odrębną jednostką"48. Sartre nie ma wątpliwości, że „moim pierwotnym upadkiem jest istnienie innego”49.

\section{Wobec anonimowego Się}

Relacje o charakterze bezosobowym ukazują jednostkę na tle ogólności (społeczeństwa), która stanowi swoistą, nieredukowalną „przestrzeń” jej egzystencji. Człowiek - wedle filozofów egzystencjalnych - stale bowiem konfrontuje się ze światem, w którym żyje, i społeczeństwem, do którego przynależy. Co znamienne, społeczeństwo (zbiorowość) jest tu postrzegane jako to, co „narzuca” jednostce określony styl życia, system wartości i sposób postępowania, afirmując jedynie to, co „bezpieczne”, a więc znane, wiadome, przewidywalne, powszechnie przyjęte i akceptowalne, co służy utrzymaniu pewności i „życiowego komfortu” ${ }^{50}$. Martin Heidegger, używając zaimka Się (das Man), definiuje nawet społeczeństwo jako „nieokreśloną mnogość”, anonimową "opinię publiczną”, która usiłuje „opanować” to wszystko, co wydaje się dla niej „niewygodne”, co „zagraża” jej powszechnemu „bezpieczeństwu". Się dąży przy tym do stłumienia tego, co w jednostce indywidualne, najbardziej własne, autentyczne. Się pragnie więc usytuować człowieka (Dasein) w „przeciętności” (Durchschnittlichkeit), odwracając jego uwagę od tego, co poza tę "przeciętność” wykracza. Jak konstatuje autor Bycia i czasu:

46 J. P. Sartre, Przy drzwiach zamkniętych, w: J. P. Sartre, Dramaty, przeł. J. Lisowski, J. Kott, PIW, Warszawa 1958, s. 176.

47 J. P. Sartre, Byt i nicość, dz. cyt., s. 305.

48 J. P. Sartre, Byt inicość, dz. cyt., s. 306.

49 J. P. Sartre, Byt i nicość, dz. cyt., s. 338.

50 M. Błaszczyk, Poza sferę bezpieczeństwa, pewności i życiowego komfortu. O egzystencjalistycznej koncepcji człowieka, w: Bezpieczeństwo w Polsce i Europie. Wybrane aspekty, red. G. Górski i in., Jagiellońskie Wydawnictwo Naukowe, Toruń 2019, s. 86-87. 
„Używamy sobie i bawimy się, tak jak się używa; czytamy, patrzymy i wydajemy sądy o literaturze i sztuce, tak jak się patrzy i sądzi; równocześnie odsuwamy się od ttumu, to jak się to zwykle robi; uznajemy za oburzające to, co się za oburzające uznaje" ${ }^{51}$. Się sprawia, że interpretujemy świat tak, jak „się” go interpretuje. Zapominamy wówczas o swojej autentyczności, oddalając się od samych siebie i innych ludzi.

Heidegger, charakteryzując „przeciętny” sposób bycia, mówi zarazem, że anonimowa "opinia publiczna” rozmywa poczucie indywidualnej odpowiedzialności, niwelując niepewność i niepokój towarzyszący ludzkim wyborom: „Się zdominowało wszelkie sądzenie i rozstrzyganie, odbiera ono aktualnemu jestestwu odpowiedzialność. Się może niejako osiągnąć to, że się stale na nie powołujemy. Bez trudu może ono odpowiadać za wszystko, bo nie jest kimś, kto musiałby za coś ręczyć" 52 . Oznacza to, że Się odciąża czy też zwalnia jednostkę z odpowiedzialności właśnie dlatego, że jest bezosobowe i ogólne (abstrakcyjne, anonimowe, zdepersonalizowane). Nie jest ono bowiem człowiekiem „z krwi i kości”, konkretnym, niepowtarzalnym i samorozumiejącym się bytem, „rzuconym” w świat (w tę, a nie inną sytuację historyczną) oraz podejmującym tę czy inną decyzję na mocy swego wolnego wyboru. Jest ono raczej abstrakcyjnym konstruktem, pewną ogólną - zastaną przez człowieka w chwili jego „wrzucenia” w świat - strukturą społeczną, która znajduje swoje umocowanie w tym, co powszednie („przeciętne”), nierefleksyjne, „lekkomyślne i niefrasobliwe”53. Podobne spostrzeżenia znajdziemy także u Sørena Kierkegaarda, odróżniającego „tłum” od „jednostki" ${ }^{4}$. Tłum (Heideggerowskie Się), jego zdaniem, zwalnia jednostkę od odpowiedzialności, niwelując jej egzystencjalne niepokoje i lęki. Zdejmuje z niej „ciężar” osobistego zaangażowania, decydowania i ponoszenia konsekwencji swoich życiowych wyborów, umacniając nieautentyczny modus istnienia.

Mówiąc inaczej, bezosobowe Się oferuje człowiekowi „wewnętrzny spokój”, „duchową równowagę”, poczucie zakorzenienia we wspólnocie, harmonii oraz życiowy komfort. Owo poczucie bezpieczeństwa, przynależności do nieproblematycznego Się, dane jest mu jednak za cenę utraty autentycznego

51 M. Heidegger, Bycie i czas, dz. cyt., s. 175.

52 M. Heidegger, Bycie i czas, dz. cyt., s. 176.

53 M. Heidegger, Bycie i czas, dz. cyt., s. 176.

54 S. Kierkegaard, Jednostka ittum, przeł. A. Ściegienny, w: S. Kierkegaard, Filozofia egzystencjalna, dz. cyt., s. 51-58. 
sposobu istnienia, do którego realizacji - jako jednostka - jest on powołany. Się nie daje zatem jednostce żadnej rękojmi co do słuszności dokonywanych przez nią wyborów. Więcej nawet: do istoty Się należy upraszczanie, ujednolicanie oraz „zaciemnianie i zakrywanie” wszystkiego, co problematyczne, co przekracza sferę „przeciętności”. Opinii publicznej nie interesuje to, co nieznane, niepewne i nieoczekiwane. A także to, co tragiczne, „wiążące”, wymagające gruntownego namysłu i osobistego zaangażowania, a przez to ontycznie najbliższe. Się nie wnika bowiem w sedno sprawy, dąży ono raczej do ukazania „przejrzystości” (a tym samym „przeciętności”) ludzkiej egzystencji. Jak zauważa Heidegger, akcentując „powierzchownośc” opinii publicznej: „To przede wszystkim ona rządzi wszelką wykładnią świata i jestestwa i ma we wszystkim rację - nie z powodu wyróżnionego i pierwotnego odniesienia w wymiarze bycia do rzeczy, nie dlatego, że dysponuje wyraźnie przyswojoną przejrzystością jestestwa, lecz z racji niewchodzenia $w$ istote sprawy, jako że jest niewrażliwa na wszelkie różnice poziomu i rzetelności. Opinia publiczna zaciemnia wszystko i tak zakryte podaje jako znane i każdemu dostępne" ${ }^{\text {55 }}$. Się dąży więc do utrzymania dotychczasowego, dominującego porządku społeczno-kulturowego, narzucając jednostce określone standardy właściwego bycia-w-świecie.

Można odnieść wrażenie, że bezosobowemu (anonimowemu) Się nie zależy, by poznać prawdę o ludzkiej egzystencji. Nie zależy mu również na tym, by poznać specyfikę relacji międzyludzkich, zbudowanych na dialogu, akceptacji i zrozumieniu. Wydaje się nawet, że kategoria „inności” pozostaje mu zupełnie obca. Się afirmuje bowiem to, co „znane”, przewidywalne i nieautentyczne, pozbawione indywidualności i wyjątkowości. Się nie jest „kimś”, z kim można nawiązać satysfakcjonującą komunikację egzystencjalną; jest raczej „bytem bez twarzy”, który jest „wszędzie i nigdzie”, nie ponosząc odpowiedzialności za promowaną wykładnię świata: „Im bardziej publicznego charakteru Się nabiera, tym mniej jest uchwytne i tym bardziej skryte" ${ }^{56}$. Heidegger wszakże dodaje, że autentyczny sposób egzystowania to bynajmniej nie całkowite odseparowanie się od Się („,jestestwo jest najpierw Się i zwykle nim pozostaje” ${ }^{57}$ ), lecz „usuwanie zakryć i zaciemnień” ${ }^{8}$, 
„Zdzieranie masek, którymi jestestwo odgradza się od samego siebie”59. Człowiek żyje więc autentycznie wówczas, gdy „na własny sposób odkrywa świat i przybliża go sobie, gdy otwiera samemu sobie swe właściwe bycie" ${ }^{60}$. Warto zaznaczyć, że Heideggerowska jednostka jest w tym procesie osamotniona. Jej samotność ma zaś wymiar ontologiczny - nie znosi jej fakt współbycia $\mathrm{z}$ innymi ludźmi ${ }^{61}$.

\section{Afirmacja Innego}

Relacje międzyludzkie, jak przekonują personaliści i filozofowie dialogu, mogą wreszcie przybrać charakter osobowy. Osoba bowiem radykalnie różni się od przedmiotu (bytu-w-sobie), nie dając się zredukować do „świata rzeczy” (bytów materialnych). Jest „kimś”, a nie „czymś” ${ }^{62}$. Jak zauważa Emmanuel Mounier: „Osoba nie jest przedmiotem. Jest ona właśnie tym, co w człowieku nie może być traktowane jako przedmiot" ${ }^{33}$. Osoby nie można tym samym poznać „z zewnątrz”, poprzez „chłodną” obserwację, lecz jedynie „od wewnątrz”, zgłębiając jej niepowtarzalność i swoistość: „Osoba nie jest najcudowniejszym przedmiotem świata, przedmiotem, który moglibyśmy poznawać z zewnątrz, jak inne. Jest ona jedyną rzeczywistością, którą poznajemy i zarazem tworzymy od wewnątrz. Wszędzie obecna, nigdy nie jest dana" ${ }^{64}$. Mikołaj Bierdiajew, dostrzegając kryzys współczesnej antropologii filozoficznej, krytykuje natomiast pogłębiający się proces dehumanizacji i depersonalizacji. Człowiek, podkreśla, zatraca swoje miejsce w świecie,

59 M. Heidegger, Bycie i czas, dz. cyt., s. 178.

60 M. Heidegger, Bycie i czas, dz. cyt., s. 178.

61 Por. M. Heidegger, Bycie i czas, dz. cyt., s. 167, 178.

62 R. Spaemann, Osoby. O różnicy między czymśa kimś, przeł. J. Merecki, Oficyna Naukowa, Warszawa 2001. Warto dodać, że „przeciwstawienie osoby i rzeczy jest podstawą filozofii personalistycznej”. M. Bierdiajew, Rozważania o egzystencji. Filozofia samotności i wspólnoty, przeł. H. Paprocki, Wydawnictwo Antyk, Kęty 2002, s. 89.

63 E. Mounier, Wprowadzenie do egzystencjalizmów, przeł. E. Krasnowolska, Znak, Kraków 1964, s. 8.

64 E. Mounier, Wprowadzenie do egzystencjalizmów, dz. cyt., s. 9. W trybie uzupełnienia przytoczmy jeszcze charakterystykę „osoby” zaproponowaną przez Bierdiajewa: „Osoba zawsze jest całością, a nie częścią, całość ta została dana wewnątrz istnienia, a nie w zewnętrznym świecie przyrody. Osoba nie jest przedmiotem i nie przynależy do zobiektywizowanego świata”. „Osoba nie jest przedmiotem, nie jest rzeczą, nie jest naturalną substancją, osoba nie jest także obiektywizacją życia psychicznego”, „w osobie ujawnia się nie świat rzeczy, a świat konkretnych żywych ludzi, żywych istot oraz ich egzystencjalnych relacji i kontaktów”. M. Bierdiajew, Rozważania o egzystencji, dz. cyt., s. 89 . 
„gubiąc” sens swojej egzystencji. Staje się zarazem coraz bardziej samotny, jego więzi z otoczeniem ulegają znacznemu nadwątleniu ${ }^{65}$.

Zatroskanie duchową kondycją człowieka jako osoby jest także charakterystyczne dla filozofii egzystencjalnej Gabriela Marcela. Godzi się przypomnieć, że uchodzi on nawet za „najwybitniejszego przedstawiciela egzystencjalizmu chrześcijańskiego" ${ }^{66}$; bywa też łączony z personalizmem i filozofią dialogu. Co ciekawe, sam Marcel określał swoją filozofię jako „neosokratyzm” lub „sokratyzm chrześcijański” ${ }^{67}$. Charakterystyczna dla jego refleksji jest bowiem nie tylko krytyka abstrakcyjnych systemów filozoficznych, ale i nieustanne zapytywanie o egzystencję konkretnego człowieka. Filozofia Marcela, podobnie jak Sokratesa, zdaje się być filozofią duchowego rozwoju, zorientowaną na poszukiwanie sensu ludzkiego istnienia.

Marcel, chcąc przezwyciężyć postępujący kryzys człowieczeństwa, mówi o prymacie „bycia” nad „posiadaniem”, nadziei nad rozpaczą. Zaznacza, że byt ludzki winien być postrzegany i definiowany nie przez to, co „posiada”, „czym” się otacza (co wokół siebie gromadzi), lecz jedynie przez to, „kim” jest jako osoba. Rozróżnienie między „byciem” a „posiadaniem” stanowi bowiem fundamentalne zagadnienie Marcelowskiego filozofowania. „W gruncie rzeczy - powie francuski filozof - wszystko sprowadza się do rozróżnienia pomiędzy tym, co się ma, a tym, czym się jest”68. „Być” znaczy więc dla Marcela tyle, co „przekraczać siebie”, „być w drodze”, a także „być z” (coesse), być w relacji z drugim człowiekiem. Mówiąc jeszcze inaczej: „być” oznacza

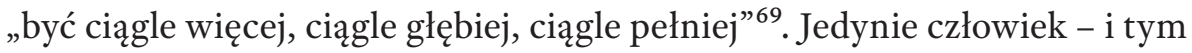
różni się on od innych wewnątrzświatowych bytów (zwłaszcza zaś od Sartre’owskich bytów-w-sobie) - może bowiem świadomie przekraczać swoją egzystencję, doświadczając jej wyjątkowości. Marcela, jak widzimy, interesuje nie sum, lecz sursum; nie „jestem”, lecz „staję się”, „transcenduję siebie”, „rosnę w górę”, „dążę ponad siebie”. Celem człowieka jako osoby jest zatem

65 Por. M. Bierdiajew, Nowe Średniowiecze. Los człowieka we wspótczesnym świecie, przeł. H. Paprocki, Fundacja Aletheia, Warszawa 2003.

66 J. Kossak, Egzystencjalizm w filozofii i literaturze, Książka i Wiedza, Warszawa 1976, s. 96.

67 Por. G. Marcel, Tajemnica bytu, przeł. M. Frankiewicz, Znak, Kraków 1995, s. 25; G. Marcel, L’homme problématique, Aubier, Paris 1955, s. 72. Zob. także X. Tilliette, Philosophes contemporains. Gabriel Marcel, Maurice Merleau-Ponty, Karl Jaspers, Desclée de Brouwer, Paris 1962, s. 9-10.

68 G. Marcel, Dziennik metafizyczny, przeł. E. Wende, PAX, Warszawa 1987, s. 240.

69 T. Terlecki, Krytyka personalistyczna. Egzystencjalizm chrześcijański, Biblioteka „Więzi”, Warszawa 1987, s. 68. Por. T. Płużański, Człowiek między ziemia a niebem, Wiedza Powszechna, Warszawa 1977 , s. 228-251. 
wykroczenie poza siebie, poza własne „ja”, zwracając się w stronę Innego i nawiązując z nim relację dialogiczną.

Pełne dialogowe otwarcie się na drugiego człowieka możliwe jest natomiast dzięki „zaangażowaniu”, partycypacji w ludzkiej wspólnocie. Dzięki niej jednostka nie tylko może przezwyciężyć swoje „wewnętrzne skostnienie”, ale i „porządek posiadania”, orientując się ku „porządkowi bycia”. Marcel przypomina, że egzystencja ex definitione jest koegzystencją. Inny pozwala mi bowiem poznać samego siebie, odsłaniając i aktywując te części mnie, na które przeważnie nie zwracam uwagi. Dzięki niemu mogę „być sobą", realizując autentyczny sposób istnienia. Inny tym samym uczestniczy w mojej egzystencji, stanowiąc jej nieodłączny komponent. „Egzystencja jest od razu zwrócona ku drugiemu, partycypująca w drugim”70; „drugi odsłania mnie dla mnie samego i pozwala mi być sobą: każdy z nas uczestniczy w byciu drugich, jest utkany z drugich"71. Spotkanie Innego, dodaje Marcel, nie oznacza tutaj uprzedmiotowienia ani „wyminięcia” go, lecz „bycie przy nim”, „bycie z nim”, współobecnośćc ${ }^{72}$. Autentyczne spotkanie ma więc charakter osobowy. Co więcej, przynależy ono do sfery „tajemnicy”, a nie „problemu”.

Przypomnijmy: „problem”, zdaniem autora Tajemnicy bytu, jest takim zagadnieniem, które można racjonalnie, „chłodno” opisać i naukowo rozstrzygnąć - bez osobistego, egzystencjalnego zaangażowania poznającego. „Problem”, można powiedzieć, pojawia się zawsze „przed” człowiekiem, który dokonuje jego interpretacji. Mamy tu bowiem do czynienia z dychotomią przedmiotu, który jest właśnie problemem do rozwiązania, i podmiotu, który usiłuje dociec do jego sedna. „Tajemnica” z kolei sytuuje się „ponad” poznającą ją jednostką, angażuje jej najbardziej własne, intymne struktury egzystencjalne. W tym też sensie nie pozwala się zobiektywizować, a wszelka próba jej konceptualizacji skazana jest na porażkę. W „tajemnicę” człowiek jest bowiem na wskroś zanurzony; w konsekwencji podział na to, co przedmiotowe, i na to, co podmiotowe, traci tu zastosowanie. Jak podkreśla sam Marcel: „Problem jest czymś, co napotykam, co znajduje się w całości przede mną i co tym samym mogę określić i ograniczyć - podczas gdy tajemnica jest czymś, w czym ja sam jestem zaangażowany i co w konsekwencji daje się

70 K. Tarnowski, Ku absolutnej ucieczce. Bóg i wiara w filozofii Gabriela Marcela, Wydawnictwo Naukowe PAT, Kraków 1993, s. 44.

71 K. Tarnowski, Ku absolutnej ucieczce..., dz. cyt., s. 44. Szerzej na ten temat zob. A. Gielarowski, Tajemnica obecności. Bycie i intersubiektywność w filozofii Gabriela Marcela, Wydawnictwo WAM, Kraków 2013, s. 56-63.

72 Por. G. Marcel, Od sprzeciwu do wezwania, przeł. S. Ławicki, PAX, Warszawa 1965, s. 19. 
pomyśleć wyłącznie jako sfera, w której rozróżnienie tego, co jest we mnie, i tego, co jest przede mną, traci swoje znaczenie i swoją wartość pierwotną. Podczas gdy autentyczny problem podlega pewnej odpowiednio przystosowanej technice, ze względu na którą się określa, to tajemnica z samej swej definicji transcenduje wszelką możliwą technikę"73. Mówiąc inaczej: „problem” dotyczy spraw, które nie są bezpośrednio związane z ludzką egzystencją, które zdają się być „na zewnątrz” niej. „Tajemnica” zaś jawi się jako „problem, który wykracza poza własne dane, przenika je i tym samym wykracza poza ramy zwykłego problemu”74. „Problem” przynależy zatem do „sfery posiadania”, „tajemnica” natomiast do „sfery bycia”.

Spotkanie jest „tajemnicą”, ponieważ angażuje całą egzystencję spotykających się osób. W akcie komunikacji z Innym jednostka nie tylko przekracza siebie, stając się bardziej sobą, lecz także odsłania się jej wówczas „pełnia bycia”, która jest celem jej egzystencjalnej wędrówki, bycia-w-drodze. Człowiek, zdaniem Marcela, jawi się bowiem jako wędrowiec (homo viator), którego egzystencja nieustannie „transcenduje siebie”, „staje się” w horyzoncie czasowym. „Bycie w sytuacji” i „bycie w drodze” - powie francuski filozof - to "dwa uzupełniające się aspekty naszego losu"75. Bycie ludzkie jest więc zawsze „byciem w drodze” (można by nawet rzec: pielgrzymowaniem), zmierzającym do urzeczywistnienia ontologicznej wspólnoty z Bogiem oraz innymi ludźmi ${ }^{76}$. Warto przy tym zaznaczyć, że transcendowanie jednostki ku Bogu i wspólnocie osób jest możliwe jedynie dzięki nadziei ${ }^{77}$. Jest ona odpowiedzią na „próbę”, która zdaje się być swoistym sprawdzianem jej człowieczeństwa, jej wewnętrznej siły w dążeniu do realizacji autentycznego życia.

73 G. Marcel, Być i mieć, przeł. P. Lubicz, PAX, Warszawa 1986, s. 10o. „Gdy zajmuję się problemem konstatuje Marcel w Tajemnicy bytu - staram się odkryć rozwiązanie, które stanie się powszechnym dobrem i w konsekwencji będzie mogło zostać ponownie odnalezione przez dowolnego człowieka”. G. Marcel, Tajemnica bytu, dz. cyt., s. 223.

74 G. Marcel, Homo viator. Wstęp do metafizyki nadziei, przeł. P. Lubicz, PAX, Warszawa 1984, s. 72.

75 G. Marcel, Tajemnica bytu, dz. cyt., s. 154.

76 Por. A. Gielarowski, Tajemnica obecności. Bycie i intersubiektywność w filozofii Gabriela Marcela, s. 91. Zob. także Cz. Piecuch, Człowiek metafizyczny, Wydawnictwo Naukowe PWN, Warszawa, Kraków 2001, s. 85-107; K. Tarnowski, Ku absolutnej ucieczce. Bógi wiara w filozofii Gabriela Marcela, dz. cyt., s. 76-8o.

77 Por. G. Marcel, Homo viator, dz. cyt., s. 48. Marcel pisze nawet, że nadzieja jest „tworzywem”, z którego zbudowana jest ludzka dusza. Por. G. Marcel, Tajemnica bytu, dz. cyt., s. 369. Szerzej na ten temat zob. S. Sarnowski, Zmierzch absolutu? Z problemów filozofii chrześcijańskiej i egzystencjalistycznej, Państwowe Wydawnictwo Naukowe, Warszawa 1974, s. 185-192. 


\section{Zakończenie}

Powyżej ukazaliśmy fenomen egzystencjalizmu, wskazując na jego programową antysystemowość, „nienaukowość” i wieloaspektowość. Zwróciliśmy przy tym uwagę na fundamentalne cechy egzystencjalnego myślenia, jak choćby prymat egzystencji nad esencją, jednostki nad zbiorowością (społeczeństwem) czy subiektywności nad ogólnością. Przyjrzeliśmy się także specyfice relacji międzypodmiotowych, nawiązując do filozofii Jeana-Paula Sartre’a, Martina Heideggera i Gabriela Marcela. Szczególnie interesująca wydaje się tu osobowa relacja z Innym - nie tylko bowiem umożliwia ona podjęcie dialogu z drugim człowiekiem, poznanie jego potrzeb, trosk czy światopoglądu, ale i odsłania pewną prawdę o nas samych, wpływając na nasze samorozumienie. Nie chodzi więc jedynie o to, że „człowiek w swoim byciu wywodzi się ze wspólnoty, jest obsługiwany przez nią i nakierowany na bycie wspólnoty"78, lecz przede wszystkim o to, że nieustannie odnosi się on do „świata rzeczy” i innych ludzi, definiując tym samym swoją egzystencję. To właśnie dzięki tej konfrontacji może lepiej rozumieć samego siebie, swoje miejsce i rolę w świecie.

Relacje międzypodmiotowe, jak mieliśmy okazję zobaczyć, mogą przybierać różne formy. Mogą bowiem prowadzić do uprzedmiotowienia Innego (Sartre), realizowania swojej autentyczności na tle „anonimowego”, bezosobowego społeczeństwa (Heidegger), mogą wreszcie prowadzić do ukonstytuowania wspólnoty osób (Marcel). Można odnieść wrażenie, dodajmy w celu uzupełnienia, że ich charakter zdaje się być wypadkową napięcia między samotnością a wspólnotowością (solidarnością). Oznacza to, że filozofowie, którzy afirmują samotność, łącząc ją z autentycznym sposobem istnienia, pozostają sceptyczni (a czasem nawet krytyczni) wobec przekonania o społecznej naturze człowieka. Podejście to reprezentują Jean-Paul Sartre i Martin Heidegger. Filozofowie, którzy autentyczność ludzkiej egzystencji wiążą z byciem we wspólnocie, podkreślają natomiast, że bycie-w-świecie jest z zasady współbyciem (koegzystencją). Tego typu konstatacje znajdziemy u Gabriela Marcela i filozofów dialogu, akcentujących - by posłużyć się określeniem Karla Jaspersa - rangę komunikacji egzystencjalnej. Temu zagadnieniu warto jednak poświęcić osobne opracowanie.

78 A. J. Heschel, Kim jest cztowiek?, przeł. K. Wojtkowska, Wydawnictwo UŁ, Wydawnictwo Punctum, Łódź, Warszawa 2014, s. 88. 


\section{Bibliografia}

Arendt H., Czym jest filozofia egzystencji?, w: H. Arendt, Salon berlinski i inne eseje, przeł. M. Godyń, S. Szymański, Prószyński i S-ka, Warszawa 2008, s. 73-102.

Arendt H., Francuski egzystencjalizm, w: H. Arendt, Salon berlinski i inne eseje, przeł.

M. Godyń, S. Szymański, Prószyński i S-ka, Warszawa 2008, s. 105-112.

Bakewell S., Kawiarnia egzystencjalistów, przeł. A. Paszkowska, Wydawnictwo Krytyki Politycznej, Warszawa 2018.

Bierdiajew M., Autobiografia filozoficzna, przeł. H. Paprocki, Wydawnictwo Antyk, Kęty 2002.

Bierdiajew M., Nowe Średniowiecze. Los człowieka we wspótczesnym świecie, przeł.

H. Paprocki, Fundacja Aletheia, Warszawa 2003.

Bierdiajew M., Rozważania o egzystencji. Filozofia samotności i wspólnoty, przeł. H. Paprocki, Wydawnictwo Antyk, Kęty 2002.

Blackham H. J., Six existentialist thinkers, Routledge \& Kegan Paul, London 1956.

Błaszczyk M., Człowiek wedtug Jeana-Paula Sartre’a, „Przegląd Filozoficzny” (2019) nr 2, s. 39-52.

Błaszczyk M., Pascal jako prekursor filozofii egzystencjalnej, „Przegląd Filozoficzny” 3 (2017), s. 149-162.

Błaszczyk M., Poza sferę bezpieczeństwa, pewności i życiowego komfortu. O egzystencjalistycznej koncepcji człowieka, w: Bezpieczeństwo w Polsce i Europie. Wybrane aspekty, red. G. Górski i in., Jagiellońskie Wydawnictwo Naukowe, Toruń 2019, s. 83-97. Błaszczyk M., Rozmowy w kawiarni. O fenomenie egzystencjalizmu, „Świat i Słowo” 2 (2019) , s. 277-284.

Bollnow O. F., Deutsche Existenzphilosophie und Französischer Existentialismus, „Zeitschrift für Philosophische Forschung" 2 (1948) H. 2/3, s. 231-243.

Bollnow O. F., Existenzphilosophie, Kohlhammer, Stuttgart 1955.

Buber M., Problem człowieka, przeł. J. Doktór, Wydawnictwo Naukowe PWN, Warszawa 1993.

Bukowski J., Problem Innego u Sartre’a, „Teksty: teoria literatury, krytyka, interpretacja" (1981) nr 3 (57), s. 142-151.

Dreyfus H., Being-with-Other, w: The Cambridge Companion to Heidegger's Being and Time, ed. M. Wrathall, Cambridge University Press, Cambridge 2013, s. 145-156.

Figal G., Martin Heidegger. Phänomenologie der Freiheit, Mohr Siebeck, Tübingen 2013. Flynn T. R., Sartre and the Poetics of History, w: The Cambridge Companion to Sartre, ed. Ch. Howells, Cambridge University Press, Cambridge 1992, s. 213-260. Friedman M., The Worlds of Existentialism, Random House, New York 1964. 
Gielarowski A., Tajemnica obecności. Bycie i intersubiektywność w filozofii Gabriela Marcela, Wydawnictwo WAM, Kraków 2013.

Gromczyński W., Człowiek, świat rzeczy, Bóg w filozofii Sartre’a, Państwowe Wydawnictwo Naukowe, Warszawa 1969.

Gromczyński W., Egzystencjalizm Jeana Paula Sartre’a, w: Filozofia XX wieku, t. 1, red. Z. Kuderowicz, Wiedza Powszechna, Warszawa 2002, s. 202-220.

Heidegger M., Bycie i czas, przeł. B. Baran, Wydawnictwo Naukowe PWN, Warszawa 2010.

Heidegger M., Czym jest metafizyka? Wprowadzenie, przeł. K. Wolicki, w: M. Heidegger, Znaki drogi, przeł. S. Blandzi i in., Wydawnictwo Spacja, Warszawa 1999, s. 313-327.

Heidegger M., Podstawowe problemy fenomenologii, przeł. B. Baran, Fundacja Aletheia, Warszawa 2009.

Heschel A. J., Kim jest człowiek?, przeł. K. Wojtkowska, Wydawnictwo UŁ, Wydawnictwo Punctum, Łódź, Warszawa 2014.

Jaspers K., Filozofia egzystencji, przeł. D. Lachowska, w: K. Jaspers Filozofia egzystencji, przeł. D. Lachowska, A. Wołkowicz, PIW, Warszawa 1990, s. 80-162.

Jaspers K., O mojej filozofii, przeł. D. Lachowska, w: K. Jaspers, Filozofia egzystencji, przeł. D. Lachowska, A. Wołkowicz, PIW, Warszawa 1990, s. 46-79.

Jaspers K., Wprowadzenie do filozofii, przeł. A. Wołkowicz, Siedmioróg, Wrocław 1998. Kaufmann W., Existentialism: from Dostoevsky to Sartre, New American Library, New York 1975.

Kierkegaard S., Jednostka i ttum, przeł. A. Ściegienny, w: S. Kierkegaard, Filozofia egzystencjalna, red. L. Kołakowski, K. Pomian, Państwowe Wydawnictwo Naukowe, Warszawa 1965, s. 51-58.

Kossak J., Egzystencjalizm w filozofii i literaturze, Książka i Wiedza, Warszawa 1976.

Levinas E., Odkrywając egzystencje z Husserlem i Heideggerem, przeł. E. Sowa, Wydawnictwo IFiS PAN, Warszawa 2008.

Luijpen W., Fenomenologia egzystencjalna, przeł. B. Chwedeńczuk, PAX, Warszawa 1972.

Marcel G., Być i mieć, przeł. P. Lubicz, PAX, Warszawa 1986.

Marcel G., Dziennik metafizyczny, przeł. E. Wende, PAX, Warszawa 1987.

Marcel G., Homo viator. Wstęp do metafizyki nadziei, przeł. P. Lubicz, PAX, Warszawa 1984.

Marcel G., L'homme problématique, Aubier, Paris 1955.

Marcel G., Od sprzeciwu do wezwania, przeł. S. Ławicki, PAX, Warszawa 1965.

Marcel G., Tajemnica bytu, przeł. M. Frankiewicz, Znak, Kraków 1995. 
Mounier E., Wprowadzenie do egzystencjalizmów, przeł. E. Krasnowolska, Znak, Kraków 1964.

Natanson M., The Problem of Others in "Being and Nothingness", w: The Philosophy of Jean-Paul Sartre, ed. P. A. Schilpp, Open Court, La Salle, Illinois 1991, s. 326-344.

Piecuch Cz., Człowiek metafizyczny, Wydawnictwo Naukowe PWN, Warszawa, Kraków 2001.

Płużański T., Człowiek między ziemia a niebem, Wiedza Powszechna, Warszawa 1977.

Roubiczek P., Existentialism. For and Against, Cambridge University Press, Cambridge 1964 .

Rymkiewicz W., Ktoś i nikt. Wprowadzenie do lektury Heideggera, Wydawnictwo Uniwersytetu Wrocławskiego, Wrocław 2002.

Sarnowski S., Zmierzch absolutu? Z problemów filozofii chrześcijańskiej i egzystencjalistycznej, Państwowe Wydawnictwo Naukowe, Warszawa 1974.

Sartre J. P., Byt i nicość. Zarys ontologii fenomenologicznej, przeł. J. Kiełbasa i in., Wydawnictwo Zielona Sowa, Kraków 2007.

Sartre J.P., Egzystencjalizm jest humanizmem, przeł. J. Krajewski, Warszawskie Wydawnictwo Literackie Muza, Warszawa 1998.

Sartre J.P., Mdtości, przeł. J. Trznadel, PIW, Warszawa 1974.

Sartre J. P., Przy drzwiach zamkniętych, w: J. P. Sartre, Dramaty, przeł. J. Lisowski, J. Kott, PIW, Warszawa 1958.

Siemek M., Nad egzystencjalizmem, w: M. Siemek, W kręgu filozofów, Czytelnik, Warszawa 1984, s. 205-213.

Spaemann R., Osoby. O różnicy między czymś a kimś, przeł. J. Merecki, Oficyna Naukowa, Warszawa 2001.

Szestow L., Ateny i Jerozolima, przeł. C. Wodziński, Znak, Kraków 1993.

Tarnowski K., Ku absolutnej ucieczce. Bóg i wiara w filozofii Gabriela Marcela, Wydawnictwo Naukowe PAT, Kraków 1993.

Tatarkiewicz W., Historia filozofii, t. 3, Wydawnictwo Naukowe PWN, Warszawa 2005.

Terlecki T., Krytyka personalistyczna. Egzystencjalizm chrześcijański, Biblioteka „Więzi”, Warszawa 1987.

Tilliette X., Philosophes contemporains. Gabriel Marcel, Maurice Merleau-Ponty, Karl Jaspers, Desclée de Brouwer, Paris 1962.

Unamuno M. de, O poczuciu tragiczności życia wśród ludzi i wśród narodów, przeł. H. Woźniakowski, Wydawnictwo Literackie, Kraków, Wrocław 1984.

Warnock M., Egzystencjalizm, przeł. M. Michowicz, Prószyński i S-ka, Warszawa 2006. Żelazny M., Filozofia i psychologia egzystencjalna, Wydawnictwo Naukowe UMK, Toruń 2011. 


\section{Abstrakt}

\section{Problem relacji międzypodmiotowych we egzystencjalizmie}

Celem artykułu będzie ukazanie specyfiki relacji międzypodmiotowych w szeroko rozumianej filozofii egzystencjalnej (egzystencjalizmie). Zaznaczymy, nawiązując do wybranych filozofów egzystencjalnych, że relacje międzypodmiotowe mogą przybierać charakter przedmiotowy (celem jest tutaj dążenie do „zawłaszczenia", uprzedmiotowienia Innego), bezosobowy (celem jest tu konfrontacja jednostki z „anonimowym” społeczeństwem, zdepersonalizowanym „tłumem”) oraz osobowy (celem jest tutaj nawiązanie dialogu, trwałej komunikacji z Innym). Będziemy argumentować na rzecz tezy, że jednostka nie jest w stanie w pełni wyjaśnić samej siebie, swego miejsca i roli w świecie, nie konfrontując swej egzystencji z Innym (drugim człowiekiem). Samorozumienie możliwe jest bowiem na drodze rozumienia Innego.

Słowa kluczowe

egzystencjalizm, relacje międzypodmiotowe, człowiek, egzystencja 
